\title{
PENGELOLAAN PEMBELAJARAN PENDIDIKAN ANAK USIA DINI DI KB CERDAS KECAMATAN BATU HAMPAR KABUPATEN ROKAN HILIR
}

\author{
AHMAD DENICO \\ STIT Dar Aswaja Rokan Hilir \\ ahmaddenidenico85@gmail.com
}

\begin{abstract}
The research was conducted at KB Smart Rokan Hilir Hamper Stone with data sources consisting of managers, educators, and students in Smart KB. The purpose of this study was to explain the management of early childhood education (PAUD) learning in Smart KB in Batu Hampar District, Rokan Hilir Regency. Data collection techniques in this study were interviews, observation, and documentation. The results of this study are (1) PAUD learning syllabus in the form of semester planning, weekly planning, and daily/meeting planning. Planning is done by paying attention to the level of development, needs, interests, and characteristics of students, and aspects of development include religious and moral, motoric, cognitive, language and social-emotional values. (2) The implementation of learning in Smart KB starts with (a) happy morning, (b) habituation activities, (c) transition, (d) environmental footing, (e) footing before playing, (f) footing during playing, (g) footing after playing, (h) introduction of prayer, and (i) closing. The implementation of learning uses the method of playing while learning through center class learning with the Beyond Center and Circle Time (BCCT) approach, and the question and answer method, stories, role-playing or direct field practice. Activities are carried out in a comfortable, safe, clean and healthy playing environment. (3) Assessment of learning in Smart KB is done by observing at any time not during the KBM until the learning is finished. through observation, recording anecdotes, and portfolios.
\end{abstract}

Keywords: Planning, Management, Assessment, Learning

\section{PENDAHULUAN}

Mewujudkan generasi yang berkualitas sangat diharapkan adanya pendidikan yang memadai untuk putra-putrinya, terlebih pada saat mereka masih berada dalam tataran usia dini. PAUD akan menjadi cikal bakal pembentukan karakter bangsa (nation character building), sebagai titik awal dari pembentukan SDM berkualitas, yang memiliki wawasan, intelektual, kepribadian, tanggung jawab, inovatif, kreatif, proaktif, dan partisipatif serta semangat mandiri. Untuk mencapai SDM berkualitas, pendidikan dimulai dari 


\section{GENERASI EMAS}

Jurnal Pendidikan Islam Anak Usia Dini

Vol. 01 No. 02, Oktober 2018

PAUD. Manajemen PAUD

diperlukan untuk meningkatkan

layanan pendidikan anak usia dini

sehingga bisa mengembangkan

potensinya secara optimal.

Undang-undang Nomor 20

Tahun 2003 tentang Sistem

Pendidikan Nasional

mengamanatkan dengan tegas

perlunya penanganan pendidikan

anak usia dini (Dinas Pendidikan

Provinsi Riau, 2012:1). Pada pasal 1

butir 14 dikatakan bahwa:

"Pendidikan anak usia dini adalah

suatu upaya pembinaan yang

ditujukan kepada anak sejak lahir

sampai dengan usia enan tahun yang

dilakukan melalui pemberian

rangsangan pendidikan untuk

membantu pertumbuhan dan

perkembangan jasmani dan rohani

agar anak memiliki kesiapan dalam

memasuki pendidikan lebih lanjut".

Selanjutnya, pada pasal 28

dinyatakan bahwa pendidikan anak

usia dini dapat diselenggarakan

melalui jalur pendidikan formal,

nonformal, dan informal. PAUD

pada jalur pendidikan nonformal

dapat berupa Kelompok Bermain

(KB), Taman Penitipan Anak (TPA), atau bentuk satuan PAUD lain yang

sederajat (Dinas Pendidikan Provinsi

Riau, 2012:1).

Pendidikan anak usia dini merupakan salah satu bentuk penyelenggaraan pendidikan yang menitikberatkan pada pengembangan pembentukan perilaku atau pembiasaan, meliputi:

perkembangan nilai-nilai agama dan moral, (2) perkembangan sosial emosional dan kemandirian dan pengembangan kemampuan dasar. Perkembangan kedua, meliputi: (a) perkembangan bahasa, (b) perkembangan kognitif, dan (c) perkembangan fisik motorik (Lilis Madyawati, 2016). Kegiatan pengembangan suatu aspek dilakukan secara terpadu dengan aspek yang lain dengan menggunakan pendekatan tematik.

Kelompok

Bermain merupakan salah satu bentuk pendidikan anak usia dini jalur pendidikan nonformal yang memberikan layanan pendidikan bagi anak usia 2-6 tahun, untuk membantu pertumbuhan dan perkembangan anak agar kelak siap memasuki pendidikan lebih lanjut. 
Pendidikannya mengutamakan

kegiatan bermain sambil belajar.

Kelompok bermain menjadi wadah untuk mengembangkan kreativitas anak dalam suatu kegiatan yang mengasyikkan. Hadi (2008:1) mengatakan mengenai konsep bermain sambil belajar seperti berikut.

"Konsep bermain sambil belajar serta belajar sambil bermain pada PAUD merupakan pondasi yang mengarahkan anak pada pengembangan kemampuan yang lebih beragam. Kebijakan pemerintah kabupaten akan ikut menentukan nasib anak serta kualitas anak di masa depan. Masa depan yang berkualitas tidak datang dengan tiba-tiba. Oleh karena itu, lewat PAUD kita bina pondasi yang kuat agar di kemudian hari anak bisa berdiri kokoh dan menjadi sosok manusia yang berkualitas".

\section{Manajemen PAUD menjadi} sangat penting diperhatikan ketika melihat kenyataan bahwa daya imajinasi, kreativitas, inovatif. dan proaktif lulusannya, berbeda secara signifikan dengan yang tidak melalui pendidikan PAUD. Hal ini penting, karena era global yang penuh dengan persaingan dan kesemrawutan (chaos) ini, diperlukan SDM berkualitas dengan daya saing tinggi agar kita tidak terus menerus tertinggal dengan negara lain. Melalui pendidikan PAUD yang berkualitas sejak anak usia dini, serta membenahi dan meningkatkan manajemen PAUD.

$$
\text { Pengelolaan merupakan }
$$
pengaturan atau managemen, dan pengajaran adalah sebuah proses belajar-mengajar. Jadi, pengelolaan pengajaran dapat diartikan suatu usaha mengatur proses belajar mengajar agar sesuai dengan konsep dan prinsip-prinsip pengajaran agar tercapai tujuan pengajaran secara efektif dan efesien.

Manajemen adalah usaha untuk mencapai suatu tujuan tertentu melalui kegiatan sejumlah kelompok aktivitas. Manajer atau pimpinan harus melaksanakan perencanaan, pengorganisasian, penempatan, penggerakan (pengarahan) dan pengendalian (TIM, 2011:86). Adapun pembelajaran adalah proses interaksi anak didik dengan pendidik dan sumber belajar pada suatu lingkungan belajar (UU Sisdiknas, 2003:4). Menurut Mulyasa (2012:256) dalam pengembangan rencana pembelajaran dinyatakan bahwa perencanaan pembelajaran 


\section{GENERASI EMAS}

Jurnal Pendidikan Islam Anak Usia Dini

Vol. 01 No. 02, Oktober 2018

PAUD meliputi perencanaan semester, rencana kegiatan mingguan (RKM), dan rencana kegiatan harian (RKH).

Berdasarkan pengertian manajemen dan pembelajaran tersebut, pengelolaan pembelajaran dapat dimaknai sebagai proses perencanaan, pengorganisasian, pelaksanaan dan penilaian kegiatan pembelajaran yang dilakukan.

Terdapat beberapa penelitian yang berkaitan dengan pengelolaan pembelajaran PAUD. Penelitian yang dilakukan oleh Logue (2007), Early childhood learning standart: tools for promoting social and academic success in kinderganten oleh Alqozzine, menyatakan bahwa keberadaan seorang guru yang berkualitas di dalam kelas sangat membantu siswa dalam meningkatkan prestasi belajarnya, dengan adanya guru yang berkualitas dapat membimbing siswa dalam memaksimalkan kualitas pembelajaran siswa tersebut.

Audra dan Neuharth-Pritchett (2006) meneliti dengan judul Developmentally Appropriate Practices in Kindergarten: factors shaping teacher beliefs and practice. Hasil penelitiannya menyatakan bahwa kegiatan pembelajaran berpusat pada anak (childreencentered). Pendidik bertindak sebagai fasilitator dan evaluator. Dengan demikian, anak dapat bermain secara aktif dan berinteraksi antar sesama anak dengan penuh kegembiraan dan suasana yang menyenangkan.

Hasil penelitian Dunn, dkk (2008) yang berjudul "impact of learning-style instructional strategieson student" menyatakan bahwa gaya pembelajaran, silabi, dapat mempengaruhi outcomes.

Michael S. Duggan, dkk (2009) dalam penelitiannya menyatakan " $A$ monitoring and evaluation framework for transformative change from sustainability programs in secondary schools". Dinyatakan bahwa suatu monitoring dan evaluasi atau penilaian ke arah yang memberi tahu perubahan transformative program, mengembangkan pendidikan efektif untuk ketahanan prakarsa, dan meramalkan potensi mereka untuk kesuksesan atau kekurangan. Jadi, dengan adanya 


\section{GENERASI EMAS}

Jurnal Pendidikan Islam Anak Usia Dini

Vol. 01 No. 02, Oktober 2018

evaluasi atau penilaian dapat mengetahui apakah kemampuan atau perkembangan siswa sudah maksimal atau belum.

Membahas kualitas pembelajaran PAUD tentu tidak terlepas dari kegiatan utamanya, yaitu proses pengelolaan pembelajaran (perencanaan, pelaksanaan dan penilaian) yang berlangsung atau dilaksanakan di lembaga PAUD yang bersangkutan. Proses pengelolaan pembelajaran yang tepat dapat menghasilkan sumber daya manusia yang berkualitas.

Berdasarkan uraian di atas, dapat dirumuskan masalah dalam penelitian ini, yakni "Bagaimana pengelolaan pembelajaran Pendidikan Anak Usia Dini (PAUD) di KB Cerdas Kecamatan Batu Hampar di Kabupaten Rokan Hilir". Dengan permasalahan itu, tujuan penelitian ini adalah untuk mengetahui pengelolaan pembelajaran Pendidikan Anak Usia Dini (PAUD) di KB Cerdas Kecamatan Batu Hampar di Kabupaten Rokan Hilir

\section{METODE PENELITIAN}

Jenis penelitian yang digunakan adalah penelitian kualitatif. Pendekatan ini diarahkan pada latar dan individu secara utuh (holistik). Dengan metode ini peneliti melakukan penelitian untuk mencari data yang bersifat deskriptif kualitatif mengenai bentuk pengelolaan pembelajaran PAUD di KB Cerdas.

Desain penelitian ini adalah etnografi. Peneliti melakukan hubungan langsung dengan subjek penelitian. Sumber data dalam penelitian ini adalah informan yang terdiri dari pengelola, pendidik dan siswa di KB Cerdas. Sumber data juga diperoleh dari data-data prota, promes, RKM dan RKH yang diperoleh dari lembaga KB ketika peneliti melakukan wawancara dan observasi di lapangan.

Teknik pengumpulan data dalam penelitian ini adalah wawancara, obsevasi, dan dokumentasi. Analisis data dalam penelitian ini menggunakan model analisis interaktif model Milles dan Huberman (Rohidi, 1999:20) yaitu pengumpulan data, reduksi data, 


\section{GENERASI EMAS}

Jurnal Pendidikan Islam Anak Usia Dini

Vol. 01 No. 02, Oktober 2018

penyajian data, dan penarikan simpulan. Validitas data dalam penelitian ini menggunakan teknik credibility (validitas internal) (Moleong, 2012:324) dan trianggulasi (Moleong,2012:330).

\section{HASIL DAN PEMBAHASAN}

\section{Perencanaan Pembelajaran di KB Cerdas Kecamatan Batu Hampar Kabupaten Rokan Hilir}

Pendidikan anak usia dini merupakan salah satu bentuk penyelenggaraan pendidikan yang menitikberatkan pengembangan pembentukan perilaku atau pembiasaan. Kegiatan pengembangan suatu aspek dilakukan secara terpadu dengan aspek yang lain denngan pendekatan tematik.

Pada rentang usia dini anak mengalami masa keemasan (the golden years) yang merupakan masa ketika anak mulai peka/sensitif untuk menerima berbagai rangsangan. Masa peka pada masing-masing anak berbeda-beda, seiring dengan laju pertumbuhan dan perkembangan anak secara individual. Masa peka adalah masa terjadinya kematangan fungsi fisik dan psikis yang siap merespon stimulasi yang diberikan oleh lingkungan. Masa dini juga merupakan masa awal untuk menggabungkan kemampuan kognitif, efektif, psikomotorik, bahasa, sosiol-emosional, dan spiritual.

Kelompok Bermain merupakan salah satu bentuk pendidikan anak usia dini jalur pendidikan nonformal yang memberikan layanan pendidikan bagi anak usia 2-6 tahun, untuk membantu pertumbuhan dan perkembangan anak, agar kelak siap memasuki pendidikan lebih lanjut. Pendidikannya mengutamakan kegiatan bermain sambil belajar, kelompok bermain menjadi wadah untuk mengembangkan kreatifitas anak dalam suatu kegiatan yang mengasikkan.

Pola belajar yang diterapakan pada anak usia dini tidaklah sama dengan pola belajar pada anak usia SD ke atas. Untuk itu, hal yang perlu diperhatikan oleh penyelenggara program PAUD adalah pengelolaan pembelajarannya. Pendidikan yang berkualitas memerlukan proses pembelajaran yang tepat, karena pengelolaan pembelajaran 


\section{GENERASI EMAS}

Jurnal Pendidikan Islam Anak Usia Dini

Vol. 01 No. 02, Oktober 2018

merupakan komponen integral dan tidak dapat dipisahkan dari proses pendidikan secara keseluruhan. Tanpa adanya manajemen atau pengelolaan yang baik, tidak mungkin tujuan pendidikan dapat diwujudkan secara optimal, efektif, dan efesien.

Membahas

kualitas pembelajaran PAUD tentu tak lepas dari kegiatan utamanya, yaitu proses pengelolaan pembelajaran (perencanaan, pelaksanaan dan penilaian) yang berlangsung atau dilaksanakan di lembaga PAUD yang bersangkutan. Proses pengelolaan pembelajaran yang tepat dapat menghasilkan sumber daya manusia yang berkualitas.

Pengelola KB Cerdas menyusun program-program kegiatan yang akan dilakukan setahun ke depan untuk memenuhi target pencapaian perkembangan anak kelompok usia 34 tahun. Program-program itu tertuang dalam silabus. Silabus pembelajaran dalam PAUD dituangkan dalam bentuk perencanaan semester, perencanaan mingguan dan perencanaan harian/ pertemuan. Perencanaan semester merupakan program pembelajaran yang dipetakan berisi jaringan tema, lingkup pembelajaran, tingkat pencapaian perkembangan, dan indikator yang ditata secara urut dan sistematis, alokasi waktu yang diperlukan untuk setiap jaringan tema, dan sebarannya ke dalam semester 1 dan 2 .

Rencana Kegiatan Mingguan (RKM) merupakan penjabaran dari perencanaan semester yang mencakup kegiatan-kegiatan dalam rangka mencapai indikator yang telah direncanakan dalam satu minggu sesuai dengan keluasan pembahasan tema dan sub tema. Rencana Pembelajaran Harian (RPH) merupakan penjabaran dari rencana kegiatan mingguan. RPH memuat kegiatan-kegiatan pembelajaran, baik yang dilaksanakan secara individual, kelompok, maupun klasikal dalam satu hari. RPH terdiri atas kegiatan pembukaan, inti dan penutup. Pembuatan RKM dan RKH bertujuan agar para pendidik memiliki panduan tentang kegiatan apa yang akan dilakukan untuk kegiatan pembelajaran selama satu pekan. 


\section{GENERASI EMAS}

Jurnal Pendidikan Islam Anak Usia Dini

Vol. 01 No. 02, Oktober 2018

Pihak pengelola memahami tingkat perkembangan anak yang akan dibina. Dalam mengembangkan rencana pembelajaran, para pendidik memperhatian tingkat perkembangan, minat, kebutuhan dan karakteristik anak didik. Hal ini dikarenakan anak usia dini memiliki karakteristik yang khas, baik secara fisik, psikis, sosial, maupun moral.

Hasil penelitian mengenai perencanaan kegiatan ini tidak bertentangan dengan penelitian Logue (2007), dalam penelitianya yang berjudul Early Childhood Learning Standart: Tools for Promoting Social and Academic Succes in Kinderganten tentang Pedoman standar pendidikan anak usia dini, dinyatakan bahwa standar pendidikan anak usia dini dirancang untuk bersatu dan membangun menuju standart untuk pendidikan K13 (yang diidentifikasi sebagai pengetahuan dan keahlian yang diperlukan untuk menyiapkan anak usia dini untuk sekolah dan memberi mereka sarana yang diperlukan untuk kesuksesan sosial, emosional, fisik dan intelegensi) merupakan sumbersumber yang belum dimanfaatkan untuk pekerja sekolah sosial dan personel Taman Kanak-Kanak.

Standart Pendidikan anak usia dini, dengan memadukan sekolah dan cita-cita pembelajaran akademik, menyediakan guru-guru dan pekerja sosial yang bertujuan mempromosikan kolaborasi pra-TK dan TK. Standart pendidikan anak usia dini dapat meningkatkan mutu pengalaman anak-anak pra-TK untuk menuju ke TK.

Dibandingkan dengan penelitian Logue (2007) terdapat persamaan dan perbedaan dengan penelitian yang dilakukan oleh peneliti. Persamaannya adalah mengenai pedoman standar pendidikan anak usia dini. Pedoman itu antara lain adalah bahwa standar pendidikan anak usia dini dirancang untuk bersatu dan membangun menuju standart untuk pendidikan K-12 yang diidentifikasi sebagai pengetahuan dan keahlian yang diperlukan untuk menyiapkan anak usia dini. Sekolah berfungsi untuk memberi mereka sarana yang diperlukan untuk kesuksesan sosial, emosional, fisik dan intelegensi dan untuk mempersiapkan mental siswa 


\section{GENERASI EMAS}

Jurnal Pendidikan Islam Anak Usia Dini

Vol. 01 No. 02, Oktober 2018

sebelum memasuki tingkat

pendidikan yang lebih tinggi.

Adapun perbedaannya adalah bahwa perencanaan pembelajaran di KB Cerdas dengan mengembangkan program-program kegiatan selama setahun untuk memenuhi target pencapaian perkembangan anak kelompok usia 3-4 tahun yang tertuang dalam silabus. Adapun silabus pembelajaran dalam PAUD dituangkan dalam bentuk perencanaan semester, perencanaan mingguan dan perencanaan harian/pertemuan. Perencanaan itu dilakukan dengan memperhatikan tingkat perkembangan, kebutuhan, minat dan karakteristik anak didik, dan aspek-aspek perkembangan meliputi nilai-nilai agama dan moral, motorik, kognitif, bahasa dan sosialemosional. Hal ini tidak terdapat pada penelitian Logue (2007) sehingga inilah yang menjadi perbedaan kedua penelitian tersebut. Perbedaan tersebut menjadi pokok pembahasan yang penulis jabarkan dalam penelitian ini.

2. Pelaksanaan Pembelajaran di KB Cerdas Kecamatan Batu Hampar Kabupaten Rokan Hilir

Pelaksanaan pembelajaran adalah operasionalisasi dari perencanaan pembelajaran sehingga tidak lepas dari perencanaan pembelajaran yang sudah dibuat. Oleh karenanya, pelaksanaan akan sangat tergantung pada bagaimana perencanaan pembelajaran.

Dalam pelaksanaan ada beberapa model pembelajaran inovatif di PAUD, yaitu: (a) model pembelajaran dengan pendekatan kelompok, (b) model pembelajaran dengan pendekatan sudut, (c) model pembelajaran dengan pendekatan area, dan (d) model pembelajaran dengan pendekatan sentra (Dinas Pendidikan Riau, 2012:14). Model pembelajaran merupakan suatu desain atau rancangan yang menggambarkan proses rincian dan penciptaan situasi lingkungan yang memungkinkan anak berinteraksi dalam pembelajaran sehingga terjadi perubahan atau perkembangan pada diri anak. Adapun komponen model pembelajaran meliput konsep, tujuan pembelajaran, tema, langkahlangkah/prosedur, metode, alat/sumber belajar, dan teknik penilaian. 


\section{GENERASI EMAS}

Jurnal Pendidikan Islam Anak Usia Dini

Vol. 01 No. 02, Oktober 2018

Sementara metode pembelajaran dapat diartikan sebagai cara yang digunakan

untuk

mengimplementasikan rencana yang sudah disusun dalam bentuk kegiatan nyata dan praktis untuk mencapai tujuan pembelajaran. Terdapat beberapa metode pembelajaran yang digunakan untuk mengimplementasikan strategi pembelajaran, diantaranya ceramah, (b) demonstrasi, (c) diskusi, (d) simulasi, (e) laboratorium, (f) pengalaman lapangan, dan lain sebagainya. Ruang lingkup program kegiatan kelompok bermain mencakup bidang pengembangan pembentukan perilaku dan bidang pengembangan kemampuan dasar melalui kegiatan bermain dan pembiasaan, dengan aspek-aspek yang dikembangkan, antara lain mencakup: (a) nilai-nilai agama dan moral, (b) fisik motorik, (c) kogntif, (d) bahasa, dan (e) sosial emosional (Dinas Pendidikan Provinsi Riau, 2012:14).

Pelaksanaan pembelajaran pendidikan anak usia dini menurut Permendiknas No 58 Tahun 2009 (DepDiknas， 2009:21) dilakukan dengan (1) penataan lingkungan bermain, dan (2) pengorganisasian kegiatan meliputi: (a) pembukaan (b) kegiatan Inti, dan (c) penutup. Sepanjang anak berada dalam lingkungan lembaga PAUD dari anak datang sampai pulang merupakan proses pembelajaran. Proses pembelajaran mencakup bidang pengembangan kemampuan perilaku dan pengembangan kemampuan dasar. Pengembangan dua bidang tersebut dilakukan melalui kegiatan bermain baik di dalam maupun di luar ruangan serta kegiatan pembiasaan. Kegiatan pembiasaan untuk mengembangkan karakter dilakukan melalui pembiasaan yang mencakup nilai-nilai agama dan moral, sopan santun, disiplin, dan lain-lain. Perkembangan pembiasaan dilakukan sejak anak datang, saat bermain, saat transisi, hingga anak pulang.

KB Cerdas dalam pelaksanaan pembelajaran diaplikasikan dengan model pembelajaran sentra aktif yang mencakup berbagai variasi kegiatan bermain seraya belajar yang merupakan ciri dari kelas berpusat pada anak (child oriented). Pelaksanaan pembelajaran di KB 


\section{GENERASI EMAS}

Jurnal Pendidikan Islam Anak Usia Dini

Vol. 01 No. 02, Oktober 2018

Cerdas Kecamatan Batu Hampar di mulai dengan: (a) happy morning, (b)

kegiatan pembiasaan, (c) transisi, (d) pijakan lingkungan, (e) pijakan sebelum main, (f) pijakan selama main, (g) pijakan setelah main, (h) pengenalan sholat, dan (i) penutup.

Happy morning adalah kegiatan penyambutan anak didik. Anak-anak diantar ke tempat penyimpanan tas, kemudian diantar ke tempat tadarus atau pengenalan Iqra'/huruf hijaiyah atau anak per anak karena KB Cerdas merupakan Islamic Fresscholl. Kegiatan pembiasaan berupa ucapan salam, selamat pagi, berdoa, tadarus surat-surat pendek, gerak diiringi nyanyian, tepuk tangan dan praktik sholat di akhir pembelajaran. Transisi dilakukan untuk memberikan jeda bagi anak yang ingin minum, training antri ke toilet, dan istirahat sejenak. Pijakan lingkungan merupakan kegiatan menyiapkan papan tulis, penghapus, spidol, buku cerita tentang air, udara, dan api. Pijakan sebelum main dilakukan dengan mengajak anak duduk melingkar, menyapa, dan mengabsen anak didik, menulis hari, tanggal, bulan, tahun, bercerita tentang kegiatan yang akan dilaksankan, membuat aturan main dan mengetahui minat anak. Pijakan selama main dilakukan dengan memberikan kesempatan pada anak untuk bermain, mengamati temannya bermain setiap anak, memperkuat dan memperluas bahasa anak melalui pertanyaan dan diskusi. Selain itu, pijakan selama main juga dilakukan dengan mendukung anak untuk menggunakan bahan bermain, memotivasi anak dalam melaksanakan kegiatan, mencatat kegiatan bermain anak dalam pengamatan, dan observasi yang merujuk pada indikator.

Pijakan setelah main dilakuakan dengan memberitahukan sisa waktu untuk bermain pada anak, sebelum mengajak anak untuk membereskan merapikan alat main, kembali duduk melingkar. Recalling: menanyakan perasaan anak selama bermain hari ini dan memberi waktu kepada anak menceritakan pangalaman mainnya. Selain itu, anak diajak anak untuk melakukan peregangan dengan bernyanyi dan gerakan-gerakan sederhana dan mengajak anak untuk membereskan serta merapikan alat bermain. 


\section{GENERASI EMAS}

Jurnal Pendidikan Islam Anak Usia Dini

Vol. 01 No. 02, Oktober 2018

Pengenalan Sholat dilakukan setelah selesai pembelajaran sentra. Anak-anak diajak untuk berwudhu dan berlatih sholat berjama'ah yang dipimpin (imam) oleh ibu guru pendidik. Setelah sholat, dilanjutkan do'a bersama untuk kedua orang tua "Allahummaghfirlii waliwaa lidayya warkhamhumma kama rabbayanii shoqhira" dan doa kebaikan dunia dan akherat "Rabbana atina fiddunya khasanah wafil akhirati khasanah waqinaa adhabannar". Selanjutnya, anak-anak belajar untuk merapikan alat-alat sholat bersama dengan guru pendidik. Penutup Setelah selesai seluruh rangkaian kegiatan anak-anak diajak doa penutup belajar sebagai tanda pembelajaran telah selesai. Selanjutnya, doa mau makan "Allahumma bariklanaa fiima razaqtana wakina adhabbannar". Doa itu dibaca pada saat anak-anak akan makan. Sebelum pulang mereka mendapatkan makan siang dari lembaga KB Cerdas. Setelah selesai makan siang, baru anak-anak diperbolehkan pulang. Sebelum pulang mereka berjabat tangan dengan guru pendidik satu per satu.
Pelaksanaan pembelajaran KB Cerdas mengacu pada prinsip belajar sambil bermain. Pengelola KB Cerdas menyadari bahwa bermain merupakan suatu kegiatan yang menyenangkan bagi anak dan mengandung makna edukatif. Kegiatan dilakukan dalam suasana bermain yang nyaman, aman, bersih, dan sehat. Setiap kelompok belajar terdiri atas 10-15 anak dengan satu orang guru pendidik. Sekolah masuk setiap hari.

Pelaksanaan pembelajarannya menggunakan beberapa sentra kegiatan bermain, antara lain sentra persiapan, sentra balok, sentra alam, sentra seni dan sentra olah tubuh. Kegiatan bermain di sentra-sentra tersebut mempunyai tujuan masingmasing, yang secara umum agar setelah melakukan kegiatan tersebut anak dapat memperoleh pengalaman yang dapat mereka terapkan dalam kehidupan mereka sehari-hari. Setiap kegiatan sentra di KB Cerdas bertujuan agar anak memperoleh kecerdasan jamak (multiple intelligences) yang diharapkan dapat berguna bagi kehidupan anak. 


\section{GENERASI EMAS}

Jurnal Pendidikan Islam Anak Usia Dini

Vol. 01 No. 02, Oktober 2018

KB Cerdas telah menggunakan metode pembelajaran yang sinergis, dengan strategi belajar sambil bermain atau bermain sambil belajar, yang di kenal dengan nama Pembelajaran Sentra atau Beyond Center and Circle Time (BBCT). Konsep belajar yang diterapkan dalam metode Sentra menghadirkan dunia nyata di dalam kelompok dan mendorong anak didik untuk membuat hubungan antara pengetahuan, pengalaman dan penerapan dalam kehidupan mereka sehari-hari. Dengan demikian, otak anak dirangsang untuk terus berfikir secara aktif dalam menggali pengalamannya sendiri, sehingga materi pelajaran yang diterima anak dapat berguna dalam jangka panjang.

Pelaksanaan pembelajaran di sentra-sentra tersebut, ketika anak belajar sambil bermain, pendidik selain menggunakan metode BCCT, juga menggunakan metode lain seperti tanya jawab, cerita, bermain peran atau praktik langsung seperti rekreasi atau berenang. Rekreasi dilakukan pada saat-saat tertentu untuk menumbuhkan kecintaan anak pada lingkungan sambil belajar.
Waktu rekreasi disesuaikan dengan tema pembelajaran sehingga lokasi kunjungan mendukung tema. Misalnya, ketika tema pembelajaran tentang binatang, anak-anak diajak mengunjungi kebun binatang.

Penelitian ini ada hubungannya dengan Penelitian Dunn, dkk. (2008) mengenai pentingnya penggunaan metode pembelajaran dalam kegiatan belajar mengajar dan penelitian tentang peranan guru dalam pembelajaran yang dilakukan oleh Alqozzine dan Quen (2007). Dari penelitian Dunn, dkk. dan Alqozzine dan Quen di atas terdapat persamaan dan perbedaan dengan penelitian yang dilakukan oleh peneliti. Persamaannya adalah dalam pelaksanaan pembelajaran, pendidik yang berkualitas, gaya pembelajaran atau metode, dan silabi dapat mempengaruhi outcomes. Perbedaannya adalah adanya spesifikasi dalam pelaksanaan pembelajaran di KB Cerdas, yakni dengan metode bermain sambil belajar melalui pembelajaran kelas sentra dengan pendekatan Beyond Center and Circle Time (BCCT) dengan jumlah siswa antara 10-15 


\section{GENERASI EMAS}

Jurnal Pendidikan Islam Anak Usia Dini

Vol. 01 No. 02, Oktober 2018

anak dan setiap kelompok sentra dengan seorang guru pendidik dan didampingi satu orang pengasuh. Metode yang digunakan pendidik adalah bermain sambil belajar dengan pendekatan BCCT, dan metode tanya-jawab, cerita, bermain peran atau praktek langsung lapangan. Konsep belajar seperti itu difokuskan agar guru sebagai pendidik dapat menghadirkan dunia nyata di dalam kelompok sentra dan mendorong anak didik membuat hubungan antara pengetahuan, pengalaman, dan penerapannya dalam kehidupan mereka sehari-hari.

\section{Penilaian Pembelajaran di KB Cerdas}

Penilaian adalah proses pengumpulan dan pengolahan informasi untuk menentukan tingkat pencapaian perkembangan anak. Penilaian proses pembelajaran dan instrumen proses hasil belajar dengan model bermain di PAUD disesuaikan dengan indikator pencapaian perkembangan anak dan mengacu pada standar penilaian. Teknik penilaian dilakukan melalui pengamatan, penugasan, unjuk kerja, pencatatan anekdot, percakapan atau dialog, laporan orang tua, dokumentasi hasil karya anak (portofolio), serta deskripsi profil anak. Lingkup penilaian mencakup seluruh tingkat pencapaian perkembangan dan pertumbuhan anak.

Waktu pelaksanaan penilaian sebenarnya dapat dilakukan sejak anak mulai belajar di sekolah dan hasilnya diberikan kepada orang tua siswa saat akhir semester. Pendidik tidak harus secara khusus membuat kegiatan seperti tes dan ujian untuk menilai anak didik.

Laporan perkembangan anak disampaikan kepada orang tua dalam bentuk laporan lisan dan tertulis secara bijak, disertai saran-saran yang dapat dilakukan orang tua di rumah (Depdiknas 58 tahun 2009: 28). Pelaporan yang diberikan kepada orang tua meliputi semua aspek perkembangan anak. Pelaporan ini dimaksudkan agar orangtua dapat mengetahui perkembangan anaknya selama belajar di lembaga kelompok bermain. Pelaporan yang diberikan kepada orang tua dalam bentuk buku laporan perkembangan anak. 


\section{GENERASI EMAS}

Jurnal Pendidikan Islam Anak Usia Dini

Vol. 01 No. 02, Oktober 2018

Penilaian pembelajaran di $\mathrm{KB}$ Cerdas dilakukan untuk mengetahui tingkat pencapaian perkembangan anak didik di lembaga. Teknik penilaian pembelajaran yang dilakukan KB Cerdas dengan 3 jenis yaitu melalui pengamatan/observasi, portofolio dan pencatatan anekdot. KB Cerdas melakukan pengamatan terhadap aktivitas anak sehari-hari mulai masuk sampai pulang. Hasil pengamatan tersebut digunakan untuk mengetahui tingkat perkembangan anak didik.

Pencatatan anekdot meliputi seluruh aktivitas anak yang positif dan negatif. Para pendidik mencatat setiap perkembangan kemampuan anak dalam hal motorik kasar, motorik halus, berbahasa, sosial, dan sosial-emosional anak. Pencatatan kegiatan tersebut dilakukan oleh tenaga pendidik dengan melihat hasil karya anak dan catatan harian mereka.

Portofolio merupakan penilaian yang didasarkan pada kumpulan hasil unjuk kerja anak yang dapat menggambarkan sejauh mana ketrampilan anak berkembang. Pelaksanaan penilaian dengan menggunakan portofolio dilakukan dengan hasil belajar anak yang berupa penugasan dan unjuk kerja. Penilaian yang dilakukan oleh guru pendidik bertujuan untuk mengetahui perkembangan kemampuan anak dalam menangkap materi pembelajaran sehingga dapat diketahui perkembangan anak.

Adanya penilaian yang dilakukan oleh pendidik dapat mengetahui peningkatan kualitas anak dalam pembelajaran. Perbedaannya adalah adanya kekhususan penilaian pembelajaran yang dilakukan di KB Cerdas yang bertujuan untuk mengetahui tingkat pencapaian perkembangan anak didik melalui pengamatan, pencatatan anekdot dan portofolio. Penilaian pembelajaran dilaksanakan setiap waktu tidak hanya saat anakanak bermain di sentra, tetapi mulai dari penyambutan anak sampai pembelajaran selesai yang tercatat dalam lembar penilaian.

\section{PENUTUP}

Simpulan penelitian ini menunjukkan bahwa perencanaan pembelajaran di KB Cerdas diawali 


\section{GENERASI EMAS}

Jurnal Pendidikan Islam Anak Usia Dini

Vol. 01 No. 02, Oktober 2018

dengan mengembangkan programprogram kegiatan selama setahun untuk memenuhi target pencapaian perkembangan anak kelompok usia 3-4 tahun yang tertuang dalam silabus. Silabus pembelajaran PAUD dituangkan dalam bentuk perencanaan semester, perencanaan mingguan dan perencanaan harian pertemuan. Perencanaan semester atau merupakan program pembelajaran yang dipetakan berisi jaringan tema, lingkup pembelajaran, tingkat pencapaian perkembangan, dan indikator yang ditata secara urut dan sistematis, alokasi waktu yang diperlukan untuk setiap jaringan tema, dan sebarannya dituangkan ke dalam semester 1 dan 2 .

Pelaksanaan pembelajaran menggunakan metode bermain sambil belajar melalui pembelajaran kelas sentra dengan pendekatan Beyond Center and Circle Time (BCCT). Jumlah siswa antara 10-15 anak setiap kelompok sentra dengan seorang guru pendidik dan didampingi satu orang pengasuh. Strategi yang digunakan pendidik adalah bermain sambil belajar dengan pendekatan BCCT, dan metode tanya jawab, cerita, bermain peran atau praktik langsung lapangan.

Penilaian pembelajaran di KB Cerdas dilakukan dengan observasi setiap saat tidak hanya pada saat anak-anak bermain di sentra, tetapi mulai dari happy morning, selama KBM berlangsung sampai selesai pembelajaran. Tujuannya untuk mengetahui tingkat pencapaian perkembangan anak didik melalui pengamatan, pencatatan anekdot, dan portofolio. Penilaian pembelajaran dilaksanakan setiap waktu tidak hanya saat anak-anak bermain di sentra.

\section{DAFTAR PUSTAKA}

Algozzine, Gretes, dan Queen. 2007. "Beginning Teachers' Perceptions of Their Induction Program Experiences". International Journal of Academic Research Library Vol. 80, Iss. 3.

Audra Parker, Stacey NeuharthPritchett. 2006. "Developmentally Appropriate Practice in Kindergarten: Factors Shaping Teacher." Journal of Research in Childhood Education; Fall 2006; 21, 1; Academic Research Library. 


\section{GENERASI EMAS}

Jurnal Pendidikan Islam Anak Usia Dini

Vol. 01 No. 02, Oktober 2018

Departemen Pendidikan Nasional, 2009. Permendiknas Nomor 58 Tahun 2009. Jakarata.

Departemen Pendidikan Republik Indonesia. 2013. Undangundang Nomor 20 Tahun 2003 tentang Sistem Pendidikan Nasional.

Dinas Pendidikan Provinsi Riau. 2012. Model Pembelajaran $P A U D$, Pekanbaru

Dinas Pendidikan Provinsi Riau. 2012. Pedoman

Pengembangan Pengelolaan Kelompok Bermain. Pekanbaru.

Dinas Pendidikan Provinsi Riau. 2012. Modul Pengembangan Kurikulum PAUD. Pekanbaru.

Dinas Pendidikan Provinsi Riau. 2012. Pedoman Pengembangan Kurikulum dan Pembelajaran PAUD Holistik Integratif. Pekanbaru

Dinas Pendidikan Provinsi Riau. 2013. Pengembangan Pembelajaran (Kurikulum) $P A U D$. Pekanbaru.

Dunn, Cheryl L., J. Owen Cherrington, Annita S. Hollander. 2005. Enterprise Information System, A PatternBassed Approach. Edisi Ketiga, New York: Mc-Graw-Hill.

Galuh, dkk. 2013 Panduan Pengembangan Kurikulum PAUD, Solo: Solopos Ceria.
Hadi. 2008. Konsep Bermain sambil Belajar dalam PAUD". http://xpresiriau.com (diakses tanggal 9 Oktober 2012).

Logue, Mary E. 2007. "Early Childhood Learning Standards: Tools for Promoting Social and Academic Success in Kindergarten." Children \& Schools; Jan 2007; 29, 1; ProQuest Education Journals.

Madyawati, Lilis. 2016. Strategi Pengembangan Bahasa pada Anak. Yogyakarta:

Mulyasa, 2012. Manajemen PAUD. Bandung: Remaja Rosdakarya.

Moleong, Lexy. 2012. Metodologi Penelitian Kualitatif. Bandung: Remaja Rosdakarya.

Rohidi, Tjejep. 1999. Analisis Data Kualitatif. Jakarta: UI Press.

TIM. 2011. Manajemen Pendidikan; Pedoman bagi Kepala Sekolah dan Guru. Surakarta: Muhammadiyah University Press. 


\section{GENERASI EMAS}

Jurnal Pendidikan Islam Anak Usia Dini

Vol. 01 No. 02, Oktober 2018 